\title{
Islamic education for early childhood in the era of society 5.0
}

\author{
Chissya El-Laudza"1,* \\ ${ }^{1}$ University of Muhammadiyah Malang, Indonesia \\ *Corresponding author: ellaudzachissya@gmail.com
}

\section{KEYWORDS \\ Society 5.0 \\ Islamic Education \\ Early Childhood Education}

SUBMITTED 15 Dec 2020

REVISED 5 Jan 2021

ACCEPTED 20 Feb 2021

\begin{abstract}
Technology and communication usage is identifiable with people of the 4.0 revolution era and is necessary for the 5.0 era that affects life aspects, such as urban planning, industry, health, transportation, agriculture, and education. This study investigates Islamic education for early childhood, especially of Qur'an learning in the era of society 5.0. The topic is significant for teachers, especially in playgroups, kindergartens, Qur'an Learning Center for Children, and parents, as it describes the urgency of technology in society 5.0 era in the educational field, especially for early childhood. As library research, this study collects and analyzes various relevant and credible data related to the issue. The study results prove that artificial intelligence, one of the characteristics of the society 5.0 era, provides significant assistance in solving various issues in the society related to Islamic education for early childhoods.
\end{abstract}

(c) The Author(s) 2021.

\section{INTRODUCTION}

Society 5.0 is a concept that focuses on humans and technology based on the Japanese government proposal. The concept develops from the 4.0 revolution, proposed in 2019 , that is considered to degrade humans' roles. Therefore, the concept is proposed to resolve the problems resulting from the industry 4.0 revolution era (Suherman, et al., 2020).

The resolution covers manufacturing and social issues with the aid of physical and virtual spaces combination. The Indonesian Law on the National Education System states that society 5.0 will affect all activities, including urban planning, industry, health, transportation, agriculture, and education (Nastiti \& Abdu, 2020).

Raising and educating children during the millennium era is a challenging task. Technology advancement that becomes more rapid has facilitated people in many ways; thus, it requires parents and teachers to supervise children in their daily activities at home and school, especially technology-usage activities. Therefore, the educational field must educate children from an early age to avoid any negative effects of the millennium era (Rsuliana, 2019).

The basic of education is to conduct transmission of values, sciences, and resilience from the older generation to the younger to survive. Meanwhile, to solve the issues, Islamic education is responsible for the guidance, training, development, and directing the children's skills and strength to function at its best (Jalaludin, 2010).

The ministry of Cultural and Education in 2019 stated that Early Childhood Education (PAUD) is the initial formal educational institution to form the characteristics of the nation's future leaders. During its development, PAUD in In- donesia has reached 230,370 institutions starting from 2019 (Latief, 2020).

Based on the regulation of the National Education System on the Early Childhood Education, there are three alternative ways to proceed, namely formal, non-formal, and informal institution for child development that consists of six parts listed in the regulation of ministry of education number 137 the year 2014 on religion and moral, physical motoric (gross and fine motor skills), cognitive (knowing and reacting towards environment), language, socioemotional, and art.

The Law of National Education System also includes religious and moral aspects that cover the ability to measure the religious aspects of every student, worship practice, honesty, being helpful, polite, respectful, sportive, cleanliness maintenance for personal purpose and environment, recognition of religious festivals, and tolerance over other religions. This study focuses on the Qur'an reading lesson, a skill that is required for all Muslims so that they can read and comprehend it with the aid of artificial intelligence. Parents and teachers will be easier in teaching early childhood students by using the technology that becomes one of society's significant characteristics 5.0.

Therefore, it is necessary to learn and master the new literacy skills in facing the society 5.0 era, namely data literacy (the skill to read, analyze, and apply big data within the digital world), technology literacy (the skill to understand machine and technology application), and human literacy (humanity, communication and design) (Suryadi, 2020).

Islamic education, early childhood, and society 5.0 are closely related to form skills within children to prepare themselves to face the society 5.0 era in ways according to Islamic teachings. 


\section{SOCIETY 5.0}

Having a different focus from the industrial revolutions of 4.0 that oriented solely to the business sector, society 5.0 abolishes the gap within society in terms of social, age, gender, and language and provides services for various individual and public needs (Nastiti \& Abdu, 2020).

On January 21, 2019, the Japanese Prime Minister proposed society 5.0 as the new social order that focuses on humans and is based on technology. Society 5.0 is preceded by the era of society 1.0 (hunting), society 2.0 (agriculture), society 3.0 (industrial), and society 4.0 (information technology) (Suherman, Musnaini, Wijoyo, \& Indrawan, 2020).

The Japanese government refers to society 5.0 as the unification of cyber and physical worlds. Social issues can be resolved in better ways as artificial intelligence facilitates data processing for the users. People with physical impairment also benefit from the data robot as a human can control it using computers and the internet. Human development, based on history, produces positive and negative impacts on humans and the environment (Suherman, Musnaini, Wijoyo, \& Indrawan, 2020).

The basic function of technology is to produce benefits at their best for the human race and keep the balance of the environment. During the era of society 4.0, technology and information were shared online, and there were difficulties to conduct partnership and cooperation. On the other hand, society 5.0 enables humans to reach the highest combination of virtual and real worlds. During this era, huge data of the real world's censors are collected in the virtual world to transform into data and analyzed using artificial intelligence; the result will be provided into the real world in various forms. According to the Japanese government, future society 5.0 will employ drones, artificial intelligence-based electronic home appliances, robots, and autonomous vehicles to travel and shop using the cloud (Suherman, Musnaini, Wijoyo, \& Indrawan, 2020).

\section{ISLAMIC EDUCATION FOR EARLY CHILDHOOD CHIL- DREN}

Islamic education pays significant concern in the building of Islamic individuals through Islamic education groups, and at the same time through the family as it is the first and foremost education centre for an individual. Furthermore, schools also take a significant role and responsibility for children's education; nevertheless, children's mental formation depends significantly on parents and school partnerships. Simultaneously, the family determines children's characteristics significantly as it is where children grow and develop, especially during their early stage of life when they can easily be formed and shaped in terms of characteristics and attitude (Mustafa, 2010).

Early childhood education aims at children around 0 to 6 years old. This education is the foundation for a comprehensive characteristics building. Therefore, the stimulation must be according to the children's needs to make them ready for a higher education level in the future (Yaswinda, Yulsyofriend, \& Sari, 2020)

Children at an early age are developing rapidly, which is the basis for their future. The learning process as the implementation of treatment inherited to children by exemplary must be according to their characteristics and the stage of age.
We often see children demonstrate their skills in front of the public during the disruption era through the internet and television. The ability to memorize, translate, and acting are some of the skills demonstrated by these children. The skills prove that the children are successful in improving their potential skills [10, hal. 20]

Having to be involved in many non-domestic activities for mothers has become one reason for the school to act as the facilitator to supervise and protect the children. The current situation has made Early Childhood Education a wise choice for parents to leave their child (PAUD). Unfortunately, most parents feel reluctant to do that as the school fee is relatively more expensive than elementary school (Herni, 2018).

In general, there are three major knowledge and skill to teach to children at an early stage (Mansur, 2005), they are:

1. Aqidah: Basic aqidah must be implanted within the children to be the basis for their faith in the future. The activities to support this plan are making the children recite Allah's holy names, tasbih, istighfar, sholawat, and short prayers.

2. Worship practice: The attempts to become an obedient servant of Allah, who does everything that Allah commands, and avoid anything He forbids.

3. Akhlak: To make children willing to eat together, wash their hands before eating, recite a short prayer before and after eating.

Despite all the school's efforts and attempts, the children's education at an early age requires an intense role from parents with proper agendas and obstacles analysis; the plan includes social factors, family form, family development stage, and role model. Therefore, a family plays a significant role in children's education (Lilawati, 2020).

Parents' role in introducing and implanting religious education, especially the Qur'an, must become the ultimate necessity and start from an early stage. Every parent has their idea and pattern for providing the best education for their children. The difference is due to the experience and knowledge every parent has. Some parents things that children at an early age need fun and enjoyable activities, including for the religious field, but some others believe that they must emphasize more discipline and a particular achievement (Islamiah, Fridani \& Supena, 2019).

Parents' problems in educating their children have become easier as society 5.0 provides artificial intelligence as a significant product that can facilitate parents better. With the AI technology, parents are no longer worried about the high educational fee they might spend to acquire some important basic skills and religious-based knowledge and a good attitude. AI can serve all those functions (Pratikno, 2017). Parents can save some of their monthly income to purchase artificial intelligence gadgets, such as Smart Pen. The tool can demonstrate how to read or recite an ayat or a surah multiple times to ensure the children hear it clearly with assistance and guidance from their parents. Another way, the current ordinary smartphone can assist parents for similar purposes by downloading the appropriate application, such as Qur'an recitation.

The Smart Pen, an AI-based gadget, refers to the learning media by using audio-visual. The media functions to focus the children's attention on increasing their learning motivation so that the learning process will run 
well and quickly, but the message/ value can be wellcomprehended (Lubis, 2014).

Johann Heinrich Pestalozzi, in his book entitled The Attractive Learning Model at Kindergarten, audio-visual media can develop children's skills such as imagination, creativity, talents, and interest. The auditorial development forces the children to improve their hearing to the maximum extent, as visual for their sights, and memory for their mind.

\section{CONCLUSION}

The Japanese government refers to society 5.0 as the unification of cyber and physical worlds. Social issues can be resolved in better ways as artificial intelligence facilitates data processing for the users. People with physical impairment also benefit from the data robot as a human can control it using computers and the internet. Human development, based on history, produces positive and negative impacts on humans and the environment.

Early childhood education aims at children around 0 to 6 years old. This education is the foundation for a comprehensive characteristics building. Therefore, the stimulation must be according to the children's needs to make them ready for a higher education level in the future.

In society 5.0 era, issues that occurred during the previous eras will no longer be a problem because there will be many gadgets that carry the Artificial Intelligence technology to facilitate the parents in educating and teaching their children about Islam, especially the Qur'an learning.

\section{REFERENCES}

Herni, Z. (2018). Pendidikan Agama Islam Pada PAUD (Penerapan Pembelajaran Sains Pada PAUD). J. Edudeena, 2(1), 1-20.

Islamiah, F., Fridani, L., \& Supena, A. (2019). Konsep Pendidikan Hafidz Qur'an pada Anak Usia Dini. J. Obs. J. Pendidik. Anak Usia Dini, 3(1), 30-38.
Jalaludin. (2010). Psikologi Agama. Jakarta: Rajawali Pres.

Latief, S. (2020). Pendidikan Anak Usia Dini (PAUD) Sebagai Pondasi Pembentukan Karakter Dalam Era Revolusi 4.0 Dan Society 5.0 Teknik Dan Keberlanjutan Pendidikan Karakter, J. Literasiologi. 3(2), 45-59.

Lilawati, A. (2020). Peran Orang Tua dalam Mendukung Kegiatan Pembelajaran di Rumah pada Masa Pandemi. J. Obs. J. Pendidik. Anak Usia Dini, 5(1), 549-558.

Lubis, E. (2014). Pengaruh media audio visual terhadap peningkatan kosakata anak usia 4-5 tahun, 1-11.

Mansur. (2005). Pendidikan Anak Usia Dini dalam Islam. Yogyakarta: Pustaka Pelajar.

Mustafa, S.F. (2010). Kurikulum Pendidikan Anak Muslim. Surabaya.

Nastiti, F.E. \& Abdu, N. (2020). Kesiapan Pendidikan Indonesia Menghadapi era society 5.0. Edcomtech J. Kaji. Teknol. Pendidik. 5(1), 61-66.

Pratikno, A.S. (2017). Implementasi Artificial Intelligence dalam Memetakan Karakteristik, Kompetensi, dan Perkembangan Psikologi Siswa Sekolah Dasar Melalui Platform Offline Conference, in Proceeding KMP Education Research Conference Keluarga Mahasiswa Pascasarjana (KMP) Universitas Negeri Yogyakarta, 18-27.

Rusliana, R. A. (2019). Perkembangan Pendidikan pada Masa Kecil Era Digital. SPEKTRUM J. Pendidik. Luar Sekol. 7(4), 445-448.

Suherman, Musnaini, H. Wijoyo, \& Indrawan, I. (2020). Industry 4.0 vs Society 5.0. Jawa Tengah.

Suryadi. (2020). Pembelajaran Era Disruptif Menuju Masyarakat 5.0. Pros. Semin. Nas. Pendidik. Progr. Pascasarj. Univ. PGRI Palembang, 16-29.

Yaswinda, Y., Yulsyofriend, Y., \& Sari, H.M. (2020). Analisis Pengembangan Kognitif dan Emosional Anak Kelompok Bermain Berbasis Kawasan Pesisir Pantai. 5(2), 9961008. 